\title{
The Influence of Nutritional Education through Puppet Play to Increasing Vegetable and Fruit Consumption in Mekar Wangi and Putra Harapan Kindergarten Children Glenmore District
}

\author{
Agus Putra Murdani', Febrika \\ Devi Nanda ${ }^{2}$, Nuris sa'datul laili ${ }^{3}$ \\ ${ }^{1}$ STIKES Banyuwangi Nutrition \\ Undergraduate Study Program \\ ${ }^{2}$ Undergraduate Public Health Study \\ Program, Universitas Bakti Indonesia \\ ${ }^{3}$ Undergraduate Public Health Study \\ Program, Universitas Bakti Indonesia \\ Email: \\ agusmurdani@stikesbanyuwangi.ac.id
} (TK).

Received : October $4^{\text {nd }} 2021$

Accepted : October $15^{\text {rd }} 2021$

Published : November $27^{\text {th }} 2021$

\section{ABSTRACT}

The consumption of vegetables and fruit is one indicator of nutritional balance. The statistical data show there are $60.44 \%$ of Indonesia that are less consuming vegetables and fruit. Fiber on vegetable and fruit are very useful for the body. Efforts to improve nutritional knowledge can preserve out through media which are suitable for children, that are attractive and easy to understand such as puppet and ladders game. This research aims to analyze the influence of the nutritional education through the game puppet to increase vegetable and fruit consumption for kindergarten children

This is a pre-research experiment. One group pre-post test. Data analysis in this study uses the sample of this research is the Mekar Wangi and Putra Harapan kindergarten children that accounted 64 people in accordance. The technique of data collection from the questionnaire is based on the direct interviews, it aims to investigate the difference in vegetable consumption on kindergarten children before nutrition education is 5,58 while after nutrition is increase to 7,75 . Whereas for fruit consumption for kindergarten children before education is 13,72 whereas after education is significantly increase to 16,47 .

The result revealed that there is an increment of education nitrition vegetable and fruit consumption after nutrition education through puppet game (Asymp.Sig =0,000) it concludes that nutritional education through puppet gameplay on an important role to increase the consumption of fruit and vegetables for kindergarten children.

Keywords: Nutrition education, puppet, vegetable consumption, fruit consumption \begin{abstract}
International License.
\end{abstract}
This is an open-acces article distributed under the terms of the Creative Commons Attribution-ShareAlike 4.0

\section{INTRODUCTION}

Nutrients are substances in food and drink that are needed by the body as a source of energy for body growth. Nutrition is an important factor to create quality human resources in the future. Nutritional support that meets the needs is very meaningful, especially in the physical growth and early development of children which will form the basis of a healthy and productive life (Achadi, 2010). 
Nutritional problems are problems that exist in every country, both developing and developed countries. Developing countries tend to have malnutrition problems that are sometimes related to infectious diseases, while developed countries have nutritional problems that are more related to degenerative diseases. Meanwhile, Indonesia is a developing country that has multiple nutritional problems, namely a combination of overnutrition and undernutrition (Depkes RI, 2014).

According to the Minister of Health Regulation No. 66 concerning Monitoring of Child Growth and Development (2014), Kindergarten children are children aged 4-6 years and at this time children are undergoing a process of rapid growth and development so that they must be used as well as possible, but these school children are among the age groups most vulnerable to being affected. Malnutrition problems that can lead to growth failure and developmental failure if not detected and intervention as early as possible can continue into adulthood. (Santoso, 2013).

National Development as the basis for the progress of a nation, one of the characteristics of an advanced nation is a nation that has a high level of health, intelligence and work productivity. These three things are influenced by nutritional status (Ministry of Health, 2014). The average consumption of fruits per capita per year is only 34.55 kilograms per capita, while consumption of vegetables as a source of fiber for health in Indonesia is only 40.35 kilograms per capita per year. This amount of consumption is far from the FAO (Food and Agriculture Organization) recommendation of 73 kilograms per capita per year and the standard of adequacy for health of 91.25 kilograms per year (CNN Indonesia, 2014).

The results of Hermina and Prihatini's research (2016), the average consumption of vegetables per person is 70.0 grams/day and fruit consumption is 38.8 grams/day. The total consumption of vegetables and fruit per person is 108.8 grams/day. Meanwhile, the recommended portion of fruit and vegetables for pre-school age children is 3 servings of fruit (300 grams). In 2014, $17 \%$ or 98 million children under five years old in developing countries experienced malnutrition, the highest prevalence was in the South Asia region of 30\%, followed by West Africa $21 \%$, Indonesia is included in the top five with the highest stunting in the world where the prevalence is in one out of every three children, which is $37 \%$. In addition, there are 9.5 million children who are malnourished (WHO, 2014). Based on research conducted by Wulandari (2014) in Desi (2015) in East Java, it shows that 44\% of preschool children are undernourished.

Various studies show that the benefits of consuming fruits and vegetables are controlling weight/overweight (obesity). Fruits and vegetables are rich in filling fiber, but low in fat and calories. Choose fruits and vegetables as a substitute for snacks that contain lots of sugar or "junk food", so your child will avoid the risk of obesity or obesity. Obese children have the potential to develop various diseases such as type 2 diabetes, high cholesterol, high blood pressure, as well as respiratory problems, depression and various other chronic diseases later in life. Adopting a healthy diet, including eating lots of fruits and vegetables can help your child perform better at school. Even research published in the Journal of School Health found that children with poor quality of eating (lack of intake of vegetables and fruit) are known to tend to get worse academic grades than those who get daily intake of vegetables and fruit. Children who usually eat a healthy menu are $41 \%$ less likely to have reading difficulties, compared to other children. Consumption of sufficient vegetables and fruit also reduces the risk of difficult bowel movements/constipation (Santoso, 2013).

One of the factors that affect a person's nutrition is the lack of knowledge about nutrition. This lack of knowledge will also reduce a person's ability to apply nutritional information in everyday life. One way to increase one's knowledge is by providing education or nutrition education as early as possible (Desi, 2015).

Educational Game Tool (APE) is a game tool that optimizes children's development. This tool contains educational value, played according to the age and level of child development (Desi, 2015). Hamalik in Azhar Arsyad (2013) in Oktavianti (2014) states that the use of learning media in teaching and learning activities can generate interest, motivation, stimulate students to learn, as well as bring psychological influence on students. Puppet media is an interesting medium to use in the learning process. In addition to teaching about Indonesian culture, wayang media can be developed into learning media that are adapted to the learning material to be studied. Basically, people know wayang only in stories or legends from Java. However, with the development of the era, wayang can be used as an educative and effective medium in learning with different packaging and attracting students' interest in learning. Puppet media can be created with easy materials. Educators can create story 
packaging that attracts students' attention to the subject matter. By combining subject matter as content in the story of wayang performances (Oktavianti, and Agus Wiyanto 2014).

\section{MATERIALS AND METHODS}

Pre-experimental design, pre-experimental research is a research design that has not been categorized as a real experiment. This is because in this design no random sampling has been carried out and sufficient control is not carried out on confounding variables that can affect the dependent variable, the pre-experimental design -experiments using different methods, but each design is given a treatment. The difference lies in the use of the pretest in the design (Yusuf, 2014).

The researcher used a pre-experimental type of research, pretest posttest design. One group pretest posttest design was a research conducted twice, namely before the experiment (pretest) and after the experiment (posttest) with one group of subjects (Arikuntoro, 2012). Drawing conclusions from Arikunto's opinion that the author gave a pretest to students to find out the extent to which students' consumption of vegetables and fruit in Mekar Wangi Kindergarten and Putra Harapan Kindergarten. After being given the initial test, they will conduct experiments by providing treatment in the form of nutrition education through puppet games. The final action taken is to give a final test (posttest) with the aim of getting a comparison of data from the initial test (pretest) to the final test (posttest).

The population in this study were 30 Class B in Mekar Wangi Kindergarten and Putra Harapan Kindergarten A total of 34 children so that the total population was 64 children. In this study the sampling technique used is. with Total Sampling. Data analysis used univariate and bivariate, namely using SPSS and the Wilcoxon Signed-Rank Test formula according to the 5\% significance level

\section{RESULTS}

\section{a. Characteristics of Respondents}

Table 4.1 Frequency Distribution of Student Characteristics by Gender

\begin{tabular}{cccc}
\hline No & Gender & Total (n) & $(\%)$ \\
\hline 1 & Man & 34 & 53,13 \\
\hline 2 & Woman & 30 & 46,88 \\
\hline \multicolumn{2}{c}{ Quantity } & 64 & 100 \\
\hline
\end{tabular}

Based on table 4.1, it can be seen that the number of male students is 34 children (53.13\%) which is greater than the number of female students as many as 30 children (46.88).

Table 4.2 Characteristics Frequency Distribution Based on Respondent Age

\begin{tabular}{clcc}
\hline No & Age & $\begin{array}{c}\text { Total students } \\
(\mathbf{n})\end{array}$ & $\mathbf{( \% )}$ \\
\hline 1 & (4-5 year) & 14 & 21,88 \\
\hline 2 & (6-7 year) & 50 & 78,13 \\
\hline & Quantity & 64 & 100 \\
\hline
\end{tabular}

Based on table 4.2, it is known that the number of students in the 4-5 year age group is 14 students $(21.88 \%)$, more than 50 students aged 6-7 years $(78.13 \%)$. 
Table 4.3 Frequency Distribution of Characteristics by Age of Parents

\begin{tabular}{clcc}
\hline No & \multicolumn{1}{c}{ Usia } & Total $(\mathbf{n})$ & $\mathbf{( \% )}$ \\
\hline 1 & $(20-23$ year $)$ & 5 & 7,81 \\
\hline 2 & $(24-25$ year $)$ & 15 & 23,43 \\
\hline 3 & $(26-27$ year $)$ & 30 & 46,87 \\
\hline 4 & ( >27 year) & 14 & 21,87 \\
\hline & Quantity & 64 & 100 \\
\hline
\end{tabular}

Based on table 4.3, it is known that the number of mother students in the age group 20-23 years is 5 people (7.81\%), 24-25 years is 15 people (23.43\%), 26-27 years is 30 people $(46.87 \%)$ and students at the age of more than 27 years there were 14 people (21.87\%), the maternal age ratio of 26-27 years was more dominant.

Table 4.4 Frequency Distribution of Characteristics Based on Parents' Last Education

\begin{tabular}{clcc}
\hline No & Last education & Total (n) & $(\boldsymbol{\%})$ \\
\hline 1 & Primary school & 7 & 10,93 \\
\hline 2 & Junior high school & 29 & 45,31 \\
\hline 3 & Senior High School & 23 & 35,93 \\
\hline 4 & College & 5 & 7,81 \\
\hline & Quantity & 64 & 100 \\
\hline
\end{tabular}

Based on table 4.4, it is known that the number of mothers in the last education group is elementary school as many as 7 people (10.93\%), junior high school as many as 29 people (45.31\%), high school as many as 23 people (35.93\%) and higher education there are 5 people $(7.81 \%)$ the most recent education is junior high school.

Table 4.5 Characteristics Frequency Distribution Based on Parents' Occupation

\begin{tabular}{llcc}
\hline No & Profession & $\begin{array}{c}\text { Total } \\
(\mathbf{n})\end{array}$ & $\mathbf{( \% )}$ \\
\hline 1 & PNS & 4 & 6,25 \\
\hline 2 & self-employed & 15 & 23,43 \\
\hline 3 & Laborer & 21 & 32,81 \\
\hline 4 & Does not work & 24 & 37,50 \\
\hline & Quantity & 64 & 100 \\
\hline
\end{tabular}

Based on table 45, it is known that the number of student mothers in the work group are civil servants as many as 4 people $(6.25 \%)$, entrepreneurs as many as 15 people $(23.43 \%)$, workers as many as 21 people (32.81\%) and 24 people not working ( $37.50 \%)$. The number of respondents who do not work is more than other jobs. 


\section{b. Results of Pre-Test Descriptive Analysis (Before Treatment)}

The results of statistical analysis on the level of nutritional knowledge and consumption of vegetables and fruits before treatment (Pre-Test) are as follows:

Table 4.6 Parental Knowledge Measurement Results

\begin{tabular}{clcc}
\hline No. & $\begin{array}{l}\text { Measurement } \\
\text { Results }\end{array}$ & Frequency & $(\%)$ \\
\hline 1. & Well & 5 & 16,22 \\
\hline 2. & Currently & 30 & 45,77 \\
\hline 3. & Not enough & 28 & 38,01 \\
\hline & Quantity & 64 & 100 \\
\hline
\end{tabular}

From table 4.6 it can be concluded that the results of measuring the knowledge of parents who scored high to low, turned out to have more moderate scores and less than good scores.

Table. 4.7 Measuring Results of Vegetable and Fruit Consumption

\begin{tabular}{llcc}
\hline No. & $\begin{array}{l}\text { Measurement } \\
\text { Results }\end{array}$ & Frequency & $(\%)$ \\
\hline 1. & Increase & 2 & 2.02 \\
\hline 2. & Permanent & 26 & 36.08 \\
\hline 3. & Decrease & 36 & 57.00 \\
\hline & Quantity & 64 & 100 \\
\hline
\end{tabular}

From table 4.7 it can be concluded that the results of measuring the consumption of vegetables and fruit at a decreasing level which got a high score of 57\% compared to those that increased or remained constant.

\section{c. Results of Post-Test Descriptive Analysis (After Treatment)}

The results of statistical analysis on the level of nutritional knowledge and consumption of vegetables and fruits after treatment (Pre-Test) are as follows:

Table 4.8 Parental Knowledge Measurement Results

\begin{tabular}{llcc}
\hline No & $\begin{array}{l}\text { Measurement } \\
\text { Results }\end{array}$ & Frequency & $(\%)$ \\
\hline 1 & Well & 44 & 55,46 \\
\hline 2 & Currently & 20 & 44,54 \\
\hline 3 & Not enough & - & - \\
\hline & Quantity & 64 & 100 \\
\hline
\end{tabular}


From table 4.8, it can be concluded that the results of measuring knowledge of parents who scored high to low, turned out to be more high scores with a total of 44 respondents (55.46\%) and moderate as many as 20 respondents $(44.54 \%)$.

Table 4.9 Measuring Results of Vegetable and Fruit Consumption

\begin{tabular}{llcc}
\hline No & $\begin{array}{l}\text { Measurement } \\
\text { Results }\end{array}$ & Frequency & $(\%)$ \\
\hline 1 & Increase & 59 & 94,5 \\
\hline 2 & Permanent & 5 & 5,5 \\
\hline 3 & Decrease & - & - \\
\hline & Quantity & 64 & 100 \\
\hline
\end{tabular}

From table 4.9 it can be concluded that the results of measuring the consumption of vegetables and fruit showed a significant increase after the nutrition education treatment, there were 59 children increased and 5 children with a fixed score $(5.5 \%)$ 
d. Bivariate analysis results

By using SPSS on the Wilcoxon test, a total of 64 respondents with pre-test and post-test experiments, so that there are data as follows:

1) Wilcoxon test

Based on the results of the Wilcoxon test, the value of negative ranks or the difference (negative) between the nutritional knowledge of the pre-test of vegetable and fruit consumption and the posttest of vegetable and fruit consumption is 0 , both in the N value, Mean Rank, and Sum Rank. This 0 value indicates an increase from the pre test value to the post test value.

Positive Ranks or difference (positive) between nutritional knowledge pre-test consumption of vegetables and fruit and post-test consumption of vegetables and fruit. Here there are 64 positive data $(\mathrm{N})$ which means that 64 respondents experienced an increase in their consumption of vegetables and fruit from the pre-test value to the post-test value. The mean rank or average increase is 16.50, while the number of positive ranks or Sum of Ranks is 528.00.

Positive Ranks or the difference (positive) between nutritional knowledge pre-test consumption of vegetables and fruit and post-test consumption of vegetables and fruit. Here there are 64 positive data $(\mathrm{N})$ which means that 64 respondents experienced an increase in the consumption of vegetables and fruit from the pre-test value to the post-test value. The Mean Rank or the average increase is 32.50 while the number of positive ranks or Sum of Ranks is 2080.00.

Based on the output of "Test Statistics" above, it is known that Asymp.Sig. (2-tailed) is worth 0.000 . Because the value of 0.000 is smaller than $<0.05$, it can be concluded that "Ha is accepted". This means that there is a difference between vegetable and fruit consumption for pre-test and posttest, so it can also be concluded that "There is an effect of Nutrition Education through Puppet Games on Increasing Vegetable and Fruit Consumption in Pre-School Children in Mekar Wangi Kindergarten and Putra Harapan Kindergarten in Glenmore District. "..

Based on the output of "Test Statistics" above, it is known that Asymp.Sig. (2-tailed) is worth 0.000 . Because the value of 0.000 is smaller than $<0.05$, it can be concluded that "Ha is accepted", meaning that there is an effect of Nutrition Education through Puppet Games on Increasing Vegetable and Fruit Consumption in Pre-School Children at Mekar Wangi Kindergarten and Putra Harapan Kindergarten in Glenmore District.

\section{DISCUSSION}

This research was conducted on September 8-13, 2020 about the effect of nutrition education through puppet games on increasing consumption of vegetables and fruit in preschool children in Mekar Wangi Kindergarten and Putra Harapan Kindergarten, Glenmore sub-district with 64 respondents.

\section{Nutrition Education}

Based on the number of parents in the age group of 20-23 years as many as 5 people (7.81\%), 24-25 years as many as 15 people (23.43\%), 26-27 years as many as 30 people (46.87\%) and students at the age of more than 27 years there were 14 people $(21.87 \%)$. Characteristics of respondents based on the number of parents by age, dominated by the age of 26-27 years as many as 30 people (46.87\%).

Age is an individual's age from birth to a few years, the older you are, the more mature a person will be in thinking and working. In terms of public trust, someone who is more mature will be more trusted than people who are not mature enough, in adulthood it is marked by physical and mental changes, skills, skills and professionals who can apply and develop science and technology as well as the arts (Nursalam et al, 2013). ).

In line with the researcher's findings, if age shows maturity in attitude, researchers are very aware of the attitude of parents aged 20-23 years having a tendency to think for themselves, as evidenced by excessive use of gadgets when accompanying children and resulting in children being less noticed by parents because they are busy. with his own world without looking at the situation and conditions. 
In the Last Education group of Parents, Elementary Education Level was 7 people (10.93\%), Middle School was 29 people (45.31\%), SMA was 23 people (35.93\%) and Higher Education was 5 people $(7,81 \%)$.

Widodo (2015) stated that the level of education of parents, especially mothers, greatly influences the success of their children, namely in terms of education. This is because a mother as a household manager spends more time with her child, it will lead to better learning outcomes for children. Other findings are research by Yuliana (2014); Wulandari (2014) states that there is a positive and significant influence between the level of parental education on student learning outcomes. The higher the educational background of parents, the higher the learning outcomes obtained by students. The results of this study are also supported by previous research by Wulandari (2014)

The learning outcomes of a student will vary greatly depending on the model of education in the family and also the level of education of both parents. When the pre-test is carried out on students who are children who have low grades, indeed the child comes from parents whose education level is only limited to elementary or junior high school and parents who have low income. However, there are also those whose parents' education level is high because they are too busy working, so parents also pay less attention to their children (I Nyoman, etc, 2016)

In line with the results of research conducted at Mekar Wangi Kindergarten and Putra Harapan Kindergarten, children with low parental education do dominate with poor measuring results compared to other children whose parents have a minimum educational background of high school, but there are also children whose parents have parents with a high enough work pressure make children less attention in terms of food consumed or less time with parents.

In the parent occupation group there are parents who work as civil servants as many as 4 people (6.25\%), entrepreneurs as many as 15 people $(23.43 \%)$, workers as many as 21 people $(32.81 \%)$ and not working there are 24 people ( $37.50 \%$ ).

Characteristics of respondents based on occupational groups dominated by parents are not working. Time for family guarantees about the quality of children's education and development, the role of parents is very important at this age. There are many children who lack attention because their parents work and rarely spend time at home with their children so that children are closer to their grandmothers or assistants, resulting in children's psychology being different from children whose parents always pay attention to their children, so they feel more valued by their parents. parents so that they motivate children to always give their best to their parents and children who are always accompanied by their parents have a higher level of concern than children who lack time to gather with their parents (Baron, 2012).

In this study, researchers found one child who was quite naughty or resourceful which caused other friends to be disturbed when receiving counseling or during normal teaching and learning activities, and it was found that this child did not receive attention from parents because of work and resulted in him often making mistakes. commotion to get attention from friends and teachers, time with family is very influential in the process of growth and development of children.

\section{Increase in Consumption of Vegetables and Fruits}

Based on table 4.2 above, it is known that the number of students in the 4-5 year age group is 14 students $(21.88 \%), 6$ years old is 50 students $(78.13 \%)$. The characteristics of the subjects in this group were mostly 6 years old, namely 50 children $(78.13 \%)$.

At the age of 4-5 years there is a rapid increase in language skills in children, because at this age they begin to actively interact with the environment, and at the age of 6 years, children have spontaneously increased their vocabulary and are better at dealing with new people or new environments, with So the language skills of 6-year-old children are better than children aged 4-5 years (Wong, 2012).

Researchers did not have too many difficulties in communicating with respondents because respondents had good language skills so it was easy to understand what was being spoken and able to interact well and could provide active feedback during nutrition counseling.

Based on gender characteristics, it can be seen that there are 34 male students $(53.13 \%)$ and 30 female students (46.88\%). Subject characteristics based on gender are more dominant than women, according to Hurlock (2011), biologically, girls generally reach maturity faster than boys. Due to the identification factor, the types of activities or games for girls are more varied and require more talk 
than activities or games for boys. At this time technology has advanced, allowing boys to get varied games with more language exploration, thereby increasing their language skills. Researchers saw that the activeness of communicating between men and women was more responsive to girls than boys, because they were too cool to be alone or embarrassed when asked questions or asked questions during counseling.

With the results of the study, it was stated that there was an effect of nutrition education through puppet games on increasing consumption of vegetables and fruit in school children at Mekar Wangi Kindergarten and Putra Harapan Kindergarten. Wayang is an interesting game in this modern era, so it is effective if it is used as a medium of information and education for children, besides educating, it also introduces original Indonesian art so that it will not be eroded by time.

\section{The Influence of Nutrition Education on Increasing Vegetable and Fruit Consumption}

In table 4.6 it can be concluded that the results of measuring parental knowledge before being given treatment got a low score or less as many as 28 respondents (38.01\%), less than 30 respondents (45.77\%), both 5 respondents (16.22\%) showed intervention amounted to 5.58 and after wayang education is shown in table 4.8 the increase in knowledge of respondents with good scores there are 44 people $(55.46 \%)$, while 20 people $(44.54 \%)$ and less (0) zero with an intervention of 7.75 with difference in increase of 2.17 .

In table 4.7 the results of measuring consumption of vegetables and fruit with a good level of 2 people (2.02\%), 26 people $(36.08 \%)$ and less as many as 36 people $(57.00 \%)$ showed an intervention of 13.72 and after education with The wayang media is shown in table 4.9. The results of measuring consumption of vegetables and fruit have increased with a good level of 59 people (94.5\%) and still 5 people (5.5\%) with 16.47 interventions with a difference of 2.75 increases.

This is in line with research conducted by Desi (2015) that the effect of nutrition education on health may be more effective if the target is directly at early childhood. Traditional games played with friends are important for children because they can train children's social and mental abilities. Traditional games and games together and doing physical activity in the form of games can repel boredom in children and stimulate the development of creativity (Desi, 2015).

Huybrechts, I., et, al, (2015) said that the need for community nutrition education programs to improve eating habits among children. Community nutrition education programs are needed to increase children's nutritional consumption and parents' awareness of the health risks arising from the consumption of deviant foods. Research assesses the health risks associated with these unhealthy eating habits of young people especially in children, deviating from age-appropriate needs. In addition, the factor that affects a person's nutrition is the nutritional intake itself, where nutritional intake will have a major impact on human health (López et.al, 2016).

Puppet play media as a tool to convey educational/teaching materials. The use of puppet game media is useful for generating interest in educational targets, motivating educational targets to carry out nutritional messages. In this study, nutrition education is able to increase the consumption of vegetables and fruit in kindergarten children, where education is one of the tools to produce changes in humans, because through education humans will be able to know everything that was not or not known before (Ngadino, 2012 ).

Nutrition education programs are the core of basic services that aim to address nutritional problems. By providing nutritional messages to optimize nutritional status through behavioral changes in food selection and provision. This is reflected in nutrition education in Hong Kong schools which is designed to be attractive and effective in inculcating healthy food habits (Yeung, 2010).

This study shows that the media with puppet games is able to increase the consumption of vegetables and fruits in kindergarten children. The media can indeed function to increase the motivation and attention of kindergarten children to learn and increase curiosity in a message, thereby increasing the consumption of vegetables and fruit for kindergarten children.

This research is supported by Desi's research (2015), which states that nutrition education through the snake and ladder model game has a significant effect on increasing hemoglobin levels and animal protein consumption. This is indicated by the significant results obtained $\mathrm{p}=0.000$. 
A similar study was conducted by Enggar Anggraini (2014), that nutrition lessons using animated media also affect nutritional knowledge. A similar study was conducted by Daluti Delimanugari (2015), stating that monopoly media is feasible or good to use as learning media.

Consumption of vegetables and fruit, children are introduced to various types of vegetables and types of fruit other than as a source of vitamins, minerals as well as a source of fiber and bioactive compounds classified as antioxidants that have functions, among others, to prevent cell damage. Fiber serves to facilitate digestion. Dietary fiber physically consists of water-soluble dietary fiber and water-insoluble dietary fiber. Both of these dietary fibers prolong the transit of food in the digestive organs (prolongs satiety) and are partially fermented by gut microbes into short-chain fatty acids. Soluble dietary fiber which is commonly found in fruits, nuts and cereals serves to slow the absorption of glucose, cholesterol and bile salts in the small intestine, thereby lowering blood sugar and cholesterol levels. Meanwhile, water-insoluble dietary fiber is useful for slowing starch digestion, helping bowel movements and launching bowel movements (Hardinsyah, 2012).

In this study, nutrition education has a significant effect on increasing consumption of vegetables and fruits in kindergarten children. This is indicated by the results of statistical analysis Paired sample ttest obtained a significance value of $\mathrm{p}$-value $=0.000$. This study is in line with Saputra Dahniman, (2016) who stated that there was a change in the provision of nutrition education through the media to changes in fruit and vegetable consumption in junior high school students.

The results of research on the impact of nutrition education in California state that coordinated nutrition education can significantly influence food consumption towards better healthy food choices (Ritchie et al, 2010). Providing nutritional information in nutrition education can promote healthy food choices (Fredman and Connos, 2011).

Based on the results and discussion above, there are significant differences in knowledge before and after providing nutrition education through puppet games to kindergarten children (Asymp. Sig = 0.000 ) and there are also significant differences in vegetable and fruit consumption before and after providing nutrition education through puppet games for children. TK (Asymp. Sig $=0.000$ ). So it is recommended that nutrition education using puppet games using cartoon images and messages on the consumption of vegetables and fruit for a healthy, active, intelligent and creative body needs to be socialized and needs to be watched because it has proven to be more effective for kindergarten children .

\section{CONCLUSION}

1. The consumption of vegetables and fruit before the pre-test was quite varied, by looking at the results of the pre-test given before the treatment, the average in terms of children's consumption had a low value of $57.00 \%$, so the researcher concluded that the willingness of each child to consume different fruits and vegetables.

2. Vegetable and fruit consumption increased after it was known that the post test results had increased significantly after the nutrition education treatment, so the researchers concluded that the consumption of vegetables and fruit increased by $37.5 \%$ after the treatment.

3. Nutrition education through wayang education has effectiveness in increasing children's willingness and knowledge. This can be proven from the results of the pre-test and post-test which showed that the post-test value increased higher than the pre-test value. From the results of the Wilcoxon test, the mean rank has increased. So it can be concluded that the hypothesis is accepted or in other words there is a significant difference between the test scores.

4. So the conclusion that can be drawn is that nutrition education through puppet games can effectively increase the consumption of vegetables and fruits in pre-school children. 


\section{REFERENCES}

Achadi. 2010. Gizi dan Kesehatan Masyarakat. Departemen Gizi dan Kesehatan Masyarakat Universitas Indonesia (UI). Jakarta: Raja Grafindo Persada.

Anggraini Enggar, Tamtomo Didik Gunawan, Hanim Diffah. (2014). Perbedaan Pengaruh Pelajaran Gizi Menggunakan Media Animasi dan Ceramah Terhadap Pengetahuan Gizi, Sikap dan Perilaku Konsumsi Buah dan Sayur Pada Anak Sekolah Dasar. Jurnal Gizi dan Kesehatan, 1(2), 169-182

Aprilia (2016), Pengaruh Penggunaan Wayang Sebagai Media Pembelajaran Sistem Gerak terhadap Minat dan Hasil Belajar Kota Semarang Tahun 2016, Skripsi, Semarang: Fakultas Matemetika Universitas Negeri Semarang.

Ardianto. 2013. Pengaruh Pendidikan Kesehatan dengan Metode Audio Visual terhadap Perilaku Cuci Tangan pada Anak Pra Sekolah di TK Aba Notoyudan. Skripsi. Yogyakarta : Fakultas Ilmu Kesehatan.

Arikunto, S. (2012). Prosedur Penelitian : Suatu Pendekatan Praktik. Jakarta : Asdi Mahasatya.

Baron, Robert, A., \& Byrne. D. (2012). Psikologi Sosial jilid 2. Jakarta: Erlangga

CNN Indoenesia, 2014. [Online] https://www.cnnindonesia.com/gaya-hidup/20160526032604-262133498/konsumsi-buah-indonesia-paling-rendah-se-asia [Diakses pada 4 Juni 2018].

Delimanugari, Daluti. (2015). Pengembangan media permainan ilmu pengetahuan alam untuk meningkatkan minat dan hasil belajar siswa MI/SD di Gunungkidul. Yogyakarta: Pascasarjana UIN Sunan Kalijaga, 2015

Departemen Kesehatan Republik Indonesia. Laporan Hasil Riset Kesehatan Dasar Indonesia (Riskesdas). 2014.

Desi, 2018. Pendidikan Gizi Melalui Permainan Wayang Terhadap Peningkatan Konsumsi Sayur dan Buah Kota Pontianak 2018, Skripsi,Jurusan Gizi, Politeknik Kesehatan Kementerian Kesehatan Pontianak, Indonesia . Tersedia di http://ejournal.poltekkespontianak.ac.id/index.php/JVK[Diakses pada 4 Juni 2018].

Desi, Hanim D. H, \& Kusnandar. (2015). Pendidikan Gizi Melalui Permainan Model Ular Tangga Untuk Meningkatkan Kadar Hemoglobin Dan Konsumsi Protein Hewani Bagi Anak Taman Kanak-Kanak, Jurnal Gizi dan Kesehatan, 2(2), 101-113.

Dyah, (2018). Panduan Gizi \& Kesehatan Anak Sekolah. Yogyakarta : CV. Andi Offset.

Freedman, M. R., \& Connors, R. (2010). Point-ofpurchase nutrition information influences foodpurchasing behaviors of college students: a pilot study. Journal of the American Dietetic Association, 110(8), 1222- 1226

Gunarjo, Nursodik. 2011. Wayang Sebagai Media Komunikasi Tradisional dalam Diseminasi Informasi. Jakarta: Kementerian Komunikasi dan Informatika RI Direktorat Jenderal Informasi dan Komunikasi Publik.

Hardinsyah dan Muhammad Aries, (2012). Jenis Pangan Sarapan dan Peranya dalam Asupan Gizi Harian Anak Usia 6-12 tahun di Indonesia. Jurnal Gizi dan Pangan, 7(2): 89-96.

Hermina dan Prihatini, (2016), Gambaran Konsumsi Sayur dan Buah Penduduk Indonesia dalam Konteks Gizi Seimbang : Analisis Lanjut Survei Konsumsi Makanan Individu (SKMI) 2014. Buletin Penelitian Kesehatan 44(3), September 2016: 205-218. 
Hurlock, E. (2011). Psikologi perkembangan suatu pendekatan sepanjang rentan kehidupan.Jakarta :Erlangga.

Huybrechts, I., Matthys, C., Vereecken, C., Maes, L., Temme, E. H., Van Oyen, H., ... \& De Henauw, S. (2008). Food intakes by preschool children in Flanders compared with dietary guidelines. International journal of environmental research and public health, 5(4), 243-257

I Nyoman Sudana Degeng, dkk, 2016. Pengaruh Latar Belakang Tingkat Pendidikan Orangtua Dan Gaya Belajar Terhadap Hasil Belajar Siswa Pada Kelas IV SDN Kecamatan Sananwetan Kota Blitar, Jurnal Pendidikan: Teori, Penelitian, dan Pengembangan Volume: 1 Nomor: 3 Bulan Maret Tahun 2016

KBBI. 2014. Konsumsi [Online]. Available: http://KBBI.Web.Id/Konsumsi

Kemenkes RI. (2014). Pedoman Gizi Seimbang. Jakarta.

Kementerian Kesehatan Republik Indonesia. Undang-Undang No.66 tentang Pemanatauan Tumbuh Kembang Anak; 2014

López, N., Morales-Suárez-Varela, M., Pico, Y., Livianos-Aldana, L., \& Llopis-González, A. (2016). Nutrient intake and depression symptoms in Spanish children: The aniva study. International Journal of Environmental Research and Public Health, 13(3), 352.

Mubarak, W.I. (2012). Promosi kesehatan untuk kebidanan. Jakarta: salemba Medik.

Ngadino. (2009). Pengembangan Media Pembelajaran. Pendidikan Profesi Guru FKIP UNS: Surakarta.

Ngadino. (2009). Pengembangan Media Pembelajaran. Pendidikan Profesi Guru FKIP UNS: Surakarta

Ningrum, D S. (2014). Peran Tokoh Punakawan Dalam Wayang Kulit Sebagai Media Penanaman Karakter di Desa Bendosewu Kecamatan Talun Kabupaten Blintar. Skripsi. Universitas Negeri Malang. Jurnal Pendidikan Kewarganegaraan Universitas Negeri Malang [online]. Vol. 11 (1), 1-11. Tersedia: http://jurnalonline.um.ac.id/data/artikel/artikel6F9B020B70EF4461EB6E975A476AF8AF. pdf. [Diakses pada 4 Agustus 2017]

Notoatmodjo, S. 2013.Promosi Kesehatan Teori dan Aplikasi, Jakarta, Rineka Cipta.

Nursalam, \& Efendi, F. 2013. Pendidikan dalam Keperawatan. Surabaya : Salemba Medika.

Nursalam, (2013). Konsep dan Penerapan Metodelogi Penelitian Ilmu Keperawatan Edisi 4. Jakarta : Salemba Medika.

Oktavianti, Rizki \& Agus Wiyanto. 2014. Pengembangan Media Gayanghetum (Gambar Wayang Hewan dan Tumbuhan) dalam Pembelajaran Tematik Terintegrasi Kelas IV SD. Mimbar Sekolah Dasar 1 (1). 65-70.

Rita, (2017). Perilaku anak Sekolah. Jakarta : PT Alex Media Komputindo.

Santoso, I. A. (2013). Serat Pangan (dietary fiber) dan manfaatnya bagi kesehatan. Magistra, 23(75), 35.

Santoso, S. \& Ranti, A. L. 2013. Kesehatan Dan Gizi. Jakarta: Rineka CiptaSediaoetama.

Saputra Dahniman, Wahyuni Yulia, \& Nuzrina R. (2016). Pengaruh Pemberian Edukasi Gizi Melalui Media Video Dan Leaflet Terhadap Perubahan Konsumsi Buah Dan Sayur Pada Siswa Smp 
Al Chasanah Tahun 2016. Program Studi Ilmu Gizi: Fakultas Ilmu-Ilmu Kesehtana Universitas Esa Unggul.

Sugiyono. 2016. MetodePenelitian Pendidikan (Pendekatan Kuantitatif, Kualitatif, $R \& D$ ). Bandung: Altabeta.

WHO. World Health Statistics 2014: World Health Organization: 2014.

Widodo, Ariyo. 2015. Hubungan Tingkat Pendidikan Orangtua dengan Motivasi Belajar Siswa SD Kelas V. (Online), (http://uny.ac.id), diakses 12 September 2015

Windi. 2016. Faktor-faktor yang Berhubungan dengan Konsumsi Buah dan Sayur Pada Anak Sekolah Dasar Kota Semarang Tahun 2016. Skripsi. Yogyakarta : Fakultas Ilmu Keolahragaan Universitas Negeri Semarang

Wong D. L., Huckenberry M.J.(2012).Wong's Nursing care of infants and children. Mosby Company, St Louis Missouri.

Wulandari, S. 2014. Hubungan Tingkat pendidikan Orangtua dengan Prestasi Belajar Siswa Kelas V A di SDN Rejondani Madurejo Prambanan Sleman Yogjakarta Semester 1 tahun Pelajaran 2012/2013. (Online), (http://posyandu.org/psikologi-anak/549-faktor-prestasi-belajarnak.html), diakses 12 September 2015.

Yeung, W. L. T. L. (2010). Gender perspectives on adolescent eating behaviors: a study on the eating attitudes and behaviors of junior secondary students in Hong Kong. Journal of Nutrition Education and Behavior, 42(4), 250-258. 